\title{
Constitutionally Short Stature: Analysis of the Insulin-Like Growth Factor-I Gene and the Human Growth Hormone Gene Cluster
}

\author{
P. E. MULLIS, M. S. PATEL, P. M. BRICKELL, AND C. G. D. BROOK \\ The Endocrine Unit [P.E.M., C.G.D.B.], The Middlesex Hospital, London WIN 8AA and the Medical Molecular \\ Biology Unit [P.E.M., M.S.P., P.M.B.], Biochemistry Department, University College and Middlesex School of \\ Medicine, London WIP 6DB, United Kingdom
}

\begin{abstract}
It has been suggested that modifications of the IGF-I gene might be responsible for constitutionally short stature (CSS). To assess this possibility, and to examine the possible role of the hGH gene cluster in CSS, we used Southern blotting and restriction fragment length polymorphism (RFLP) linkage analysis to study 57 children with CSS, including 17 children from 10 families with CSS. We studied as control populations 50 children and 25 adults of normal height, including three families, and 60 children with isolated growth hormone deficiency. No gross structural abnormalities of the IGF-I gene or the hGH gene cluster were found in any of the subjects. The allelic frequencies for each of two distinct RFLP associated with the IGF-I gene (EcoRV and HindIII/PvuII) and for each of five distinct RFLP associated with the hGH gene cluster $[B g l \mathrm{II}(\mathrm{A}), \quad B g l \mathrm{II}(\mathrm{B}), \quad M s p \mathrm{I}(\mathrm{A}), \quad M s p \mathrm{I}(\mathrm{B}), \quad$ and HincII] were the same in the CSS, isolated growth hormone deficiency, and normal populations, and the RFLP haplotypes for both the IGF-I gene and the hGH gene cluster also appeared with the same frequency in all three populations. Analysis of the families that contained heterozygotes for the HindIII/PvuII and/or EcoRV IGF-I RFLP excluded a linkage of the IGF-I gene to CSS in these families. Assuming that the inheritance is dominant, the lod score at $1 \%$ recombination was -2.2 , whereas assuming a recessive inheritance, the lod score at $1 \%$ recombination was $\mathbf{- 1 . 9 3}$. Linkage analysis and the lack of any significant association between CSS and a particular allele of the IGF-I gene or the hGH gene cluster fail to provide support for the suggestion that major modifications of these genes are involved in the growth failure of individuals with CSS. (Pediatr Res 29: 412-415, 1991)
\end{abstract}

\section{Abbreviations}

CSS, constitutionally short stature

GH, growth hormone

IGHD, isolated growth hormone deficiency

RFLP, restriction fragment length polymorphism

Multiple biochemical processes in a well-regulated cascade are involved in the pathway leading to normal growth. These begin with hypothalamic control of GH synthesis and secretion from the pituitary gland and end with the action of peptide hormones,

Received July 11, 1990; accepted November 12,1990.

Correspondence and reprint requests: Prof. C. G. D. Brook, The Middlesex Hospital, Mortimer Street, London WIN 8AA, UK.

Supported by grants from Schweizerische Stiftung für Medizinisch-Biologische Stipendien (P.E.M.) and by the Leukaemia Research Fund (M.S.P.). of which IGF-I is the best known, on target tissues such as cartilage, bone, and muscle (1). The amount of hGH secreted over $24 \mathrm{~h}$ in short children is asymptotically related to height velocity (2), and children who are short but growing along or parallel to the 3rd height centile will respond to recombinant hGH treatment $(3,4)$. Although these individuals present with normal hGH secretion after standard stimulation tests (5), they often show a phenotypic resemblance to children with IGHD, but are taller. However, we have to emphasize that a normal peak GH concentration after provocative stimulation tests (6) does not exclude physiologic GH deficiency.

We postulated that among the underlying defects there might be abnormalities in the hGH gene cluster or the IGF-I gene because its expression is regulated by $\mathrm{hGH}(7)$ and IGF-I plays a pivotal role in normal growth (1). hGH is a 22.000 molecular weight protein consisting of 191 amino acid residues. The hGH gene cluster consists of five closely related genes in the $5^{\prime}(\mathrm{hGH}$ 1, hCS-L, hCS-A, hGH-2, hCS-B) 3', encompassing approximately $66.5 \mathrm{~kb}$ on the long arm of chromosome 17 (8). IGF-I is a 70 -amino acid peptide hormone encoded by a gene extending over more than $85 \mathrm{~kb}$ on the long arm of chromosome $12(9$, $10)$.

In two recent studies, the structure of the IGF-I gene was analyzed in subjects with constitutionally variant stature (11, 12 ). In one of the studies, a significantly decreased prevalence of one allele of an EcoRV RFLP associated with the IGF-I gene was found in children with CSS (12), and it was suggested that this might indicate a role for minor abnormalities of the IGF-I gene in CSS.

We have analyzed the IGF-I gene and the hGH gene cluster in children with CSS to determine whether a significant number had a gross structural alteration in these genes or whether CSS was associated with particular RFLP alleles, which might suggest a role for minor structural abnormalities. We also performed IGF-I gene RFLP linkage analysis in 10 families with CSS. A further aim was to assess the priority of searching the IGF-I gene locus in detail for basic molecular defect of CSS, as has been suggested (12).

\section{SUBJECTS AND METHODS}

Subjects. Fifty-seven prepubertal children [age: 4.1-11.9 y; bone age: $2.5-9.5$ y; sex: 18 females, 39 males; height standard deviation score: -3.6 to -2.5 , mean height velocity standard deviation score: -0.35 (SD 0.25)] with CSS attending the Growth Disorder Clinic at the Middlesex Hospital in London were studied. These included 17 children with CSS (seven females, 10 males) from 10 families. In each of these families, one parent presented with $\operatorname{CSS}(n=10$; five females, five males; height standard deviation score: -3.4 to -2.5 ) and came from a family with CSS, whereas the other was of normal height for sex (13). 
We also analyzed eight siblings of normal height for age and sex (13) from these families. The criteria for the categorization of CSS included no demonstrable causes of short stature; in particular, normal body proportion $(13,14)$, normal birth weight and length (13), exclusion of Turner's syndrome in girls, stature -2.5 standard deviation score or less for chronologic age and sex (13), a peak hGH level of more than $10 \mu \mathrm{g} / \mathrm{L}$ after standard pharmacologic stimulation and an height velocity within normal range ( $>25$ percentile; $>-0.8$ SDS). Standard auxologic assessment was performed (15). No child had evidence of organic disease, psychosocial deprivation, or any eating disorder, and all had normal renal and hepatic function.

Controls were 60 unrelated children with IGHD (criteria are described in ref. 16), 50 unrelated normal children of normal height (13), and 25 adults of normal stature (13), including individuals from three families. Demonstration of normal hGH secretion was undertaken using insulin-induced hypoglycemia. Blood glucose less than $2 \mathrm{mmol} / \mathrm{L}$ was achieved in all cases. This test was combined with exogenous administration of thyrotropinreleasing hormone $(200 \mu \mathrm{g})$ and gonadotropin-releasing hormone $(100 \mu \mathrm{g})$ to test the remainder of hypothalamo-pituitary axis. All subjects were taken from the British Caucasian population and children of Mediterranean, Asian, African, and Semitic descent were excluded from the study, inasmuch as different allelic frequencies for RFLP have been reported in populations of different racial origin $(17,18)$.

Hormone assay. Serum hGH concentrations were measured using a Tandem-R Immunoradiometric kit (Hybritech, Nottingham, UK) (19). The interassay coefficient of variation was $9.2 \%$ at $2.0 \mathrm{mU} / \mathrm{L}$ and the intraassay coefficient of variation at $\mathrm{GH}$ concentrations of $0.7,2.0,6.5$, and $13.0 \mathrm{mU} / \mathrm{L}$ were 10.6 , $6.3,3.5$, and $3.25 \%$, respectively. The working standard was HS 244.3 E (NIH, Bethesda, MD), which was recalibrated using the International Reference Preparation of hGH [NIBSC, South Mimms, UK: code no. 66 (217)]. Blood glucose concentrations were measured using the YSI 23 AM glucose analyzer (Yellow Springs Instrument Co., Yellow Springs, $\mathrm{OH}$ ).

Gene probes. The recombinant plasmid phu $\mathrm{GH} 1$ contained a nearly full-length $(816 \mathrm{bp}) \mathrm{hGH}$ cDNA insert in the Pst $\mathrm{I}$ site of pAT 153. The nucleotide sequence of this insert is identical to that of the hGH cDNA clone chGH800/pBR322 (20). The recombinant plasmid phigf $1 \mathrm{~A}$ is a cDNA clone containing the $5^{\prime}$ untranslated region, coding region, and part of the $3^{\prime}$ untranslated region corresponding to the IGF-IA mRNA (21). The 816bp PstI insert of phu GHI and a 660-bp EcoRI/BamHI fragment of the phigf $1 \mathrm{~A}$ were labeled with $\left(\alpha{ }^{32} \mathrm{P}\right)$-deoxycytosine triphosphate ( $3000 \mathrm{Ci} / \mathrm{mmol}$; New England Nuclear Ltd., Boston, MA) by the random primer method of Feinberg and Vogelstein (22).

Southern blotting analysis. Genomic DNA was prepared from peripheral blood leucocytes as previously described (16). Samples of genomic DNA $(10 \mu \mathrm{g})$ were digested to completion with restriction enzymes ( $B a m \mathrm{HI}, B g l \mathrm{I}, B g l \mathrm{II}, E c o \mathrm{RI}, E c o \mathrm{RV}$, HincII, HindIII, MspI, PstI, PvuII) under conditions recommended by the suppliers (Boehringer Mannheim, London, UK). After electrophoresis in $0.5-1.2 \%$ (wt/vol) agarose gels, the DNA frag-

Table 1. Allelic frequencies (\%) of HindIII/PvuII and EcoRV RFLP associated with the IGF-I gene in unrelated normal children, unrelated children with IGHD, and unrelated subjects with CSS*

\begin{tabular}{|c|c|c|c|}
\hline & $\begin{array}{l}\text { Controls } \\
(n=57)\end{array}$ & $\begin{array}{c}\text { IGHD } \\
(n=60)\end{array}$ & $\begin{array}{c}\text { CSS } \\
(n=40)\end{array}$ \\
\hline \multicolumn{4}{|l|}{ HindIII/PvuII } \\
\hline $5.2 \mathrm{~kb} / 5.1 \mathrm{~kb}$ allele & 20 & 21 & 19 \\
\hline $4.8 \mathrm{~kb} / 4.7 \mathrm{~kb}$ allele & 80 & 79 & 81 \\
\hline \multicolumn{4}{|l|}{ EcoRV } \\
\hline $13.0 \mathrm{~kb}$ allele & 8 & 7 & 7 \\
\hline $11.5 \mathrm{~kb}$ allele & 92 & 93 & 93 \\
\hline
\end{tabular}

* The HindIII and PvuII RFLP are coinherited. ments were transferred to nylon membranes (Hybond-N, Amersham International, UK), according to the manufacturer's instructions, prehybridized for at least $3 \mathrm{~h}$ at $65^{\circ} \mathrm{C}$ in $6 \times \mathrm{SSPE}, 5$ $\times$ Denhardt's solution, $0.5 \%$ SDS, $10 \%$ dextran sulphate, $50 \mu \mathrm{g} /$ $\mathrm{mL}$ denaturated sonicated salmon sperm DNA, and then hybridized overnight at $65^{\circ} \mathrm{C}$ in prehybridization solution containing $10^{6} \mathrm{cpm} / \mathrm{mL}$ of the hGH or the IGF-I probe. The filters were then washed at $65^{\circ} \mathrm{C}$ in $2 \times \mathrm{SSC}, 0.1 \%$ SDS (twice for $30 \mathrm{~min}$ each) and $0.2 \times \mathrm{SSC}, 0.1 \%$ SDS (twice for $30 \mathrm{~min}$ each), respectively, and autoradiographed at $-70^{\circ} \mathrm{C}$ using intensifying screens (23).

Statistics. The $\chi^{2}$ test was used to compare the frequencies of RFLP alleles and the distribution of distinct haplotypes.

\section{RESULTS}

Analysis of the IGF-I gene. The pattern of hybridizing fragments generated by BamHI, BglI, BglII, EcoRI, HinclI, MspI, and $P s t I$ were identical for all individuals studied, showing that no gross structural abnormalities of the IGF-I gene were present in children with CSS or IGHD.

The allelic frequencies of the three previously described RFLP of the IGF-I gene (HindIII, PvuII, EcoRV) $(10,18,24)$ in unrelated subjects are shown in Table 1 . The HindIII and PvuII RFLP are coinherited $(10,18)$. There was no difference in the allelic frequencies between normal children, children with IGHD, and children with CSS.

In addition to this study of unrelated individuals, we studied 10 families with CSS. Of the 10 families studied, six contained heterozygotes for the HindIII/PvuII RFLP $(5.2 \mathrm{~kb}, 4.8 \mathrm{~kb} / 5.1$ $\mathrm{kb}, 4.7 \mathrm{~kb}$ ) and three contained heterozygotes for the EcoRV RFLP (13.0 kb, $11.5 \mathrm{~kb})$ (Fig. 1). Of these, with respect to the trait, two families were informative for the HindIII/PvuII IGF-I gene RFLP and two families were informative for the EcoRV IGF-I RFLP. Linkage analysis excluded the possibility of the IGF-I gene exerting a dominant effect in CSS in these families. The lod score for an assumed dominant inheritance of CSS at $1 \%$ recombination was -2.2 and -1.93 for an assumed recessive inheritance, respectively (25).

Analysis of the $h G H$-gene cluster. The frequencies for all five common RFLP of the hGH gene cluster in unrelated subjects with CSS are shown in Table 2. The frequency of the different alleles in subjects with CSS did not differ from those that we previously described in children with IGHD and children of normal height (16).

The different hGH gene cluster haplotypes in 10 families with CSS are shown in Table 3. One parent in each of these 10 families was of normal stature $(n=10)$ and eight of the children (eight of 25) were of normal height for chronologic age and sex (13). These 18 subjects are shown as controls in Table 3 . We were unable to include the $B g / \mathrm{II}(\mathrm{B}) \mathrm{RFLP}$ in this analysis because of problems in discriminating the different genotypes (16). The frequency of appearance of each haplotype showed no significant difference between the subjects with CSS and the control group. There was no significant difference between the frequencies of appearance of the haplotypes in the CSS group and in the normal population and children with IGHD.

\section{DISCUSSION}

We used Southern blotting to analyze the structure of the IGFI gene and the hGH gene cluster in children with CSS. There were no major structural abnormalities of the IGF-I locus in subjects with CSS and/or IGHD. The allelic frequencies for the coinherited HindIII and PvuII RFLP in the British population (Table 1) were similar to those found in France and the United States $(11,12)$ and did not vary between normal and CSS populations. A decreased frequency of the $13.0-\mathrm{kb}$ allele of the EcoRV RFLP (13 kb/11.5 kb) in French children with CSS (4\%) in comparison with a control French population (13\%) has been 
Hind III / Pvu II RFLP

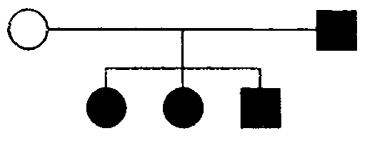

111
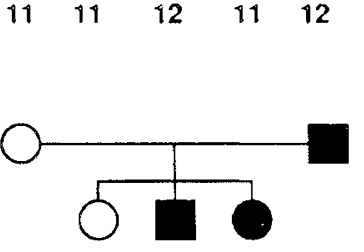

$\begin{array}{lllll}12 & 11 & 11 & 12 & 11\end{array}$

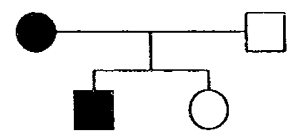

1211

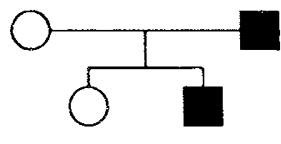

1212
1211

$11 \quad 11$

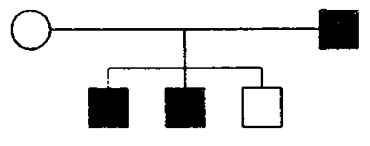

$\begin{array}{lllll}12 & 11 & 12 & 11 & 11\end{array}$

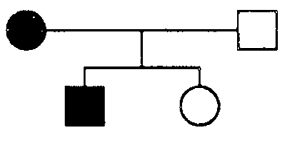

$\begin{array}{llll}11 & 12 & 11 & 12\end{array}$

Eco RV RFLP
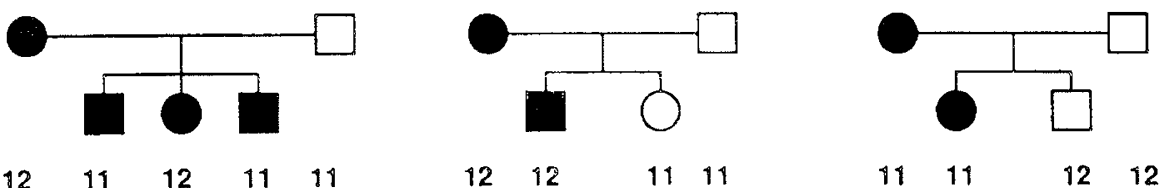

Fig. 1. Pedigrees of families with CSS. Six of the 10 families studied contained heterozygotes for the HindIII/PvuII RFLP $(5.2 \mathrm{~kb}, 4.8 \mathrm{~kb} / 5.1 \mathrm{~kb}$, $4.7 \mathrm{~kb})$ and three families contained heterozygotes for the EcoRV RFLP $(13.0 \mathrm{~kb}, 11.5 \mathrm{~kb})$. The pattern of inheritance of the coinherited HindIII/ $P v u l I$ RFLP and the EcoRV RFLP is shown below each symbol: $I$ indicates the shorter, more common fragment of each polymorphic restriction fragment (HindIII: $4.8 \mathrm{~kb} ; P v u I I: 4.7 \mathrm{~kb} ; E c o \mathrm{RV}: 11.5 \mathrm{~kb}$ ) and 2 indicates the longer fragment (HindiII: $5.2 \mathrm{~kb} ; P v u I I: 5.1 \mathrm{~kb} ; E c o \mathrm{RV}: 13.0 \mathrm{~kb}$ ). Solid symbols denote affected family members, circles female family members, and squares male family members.

Table 2. Allelic frequencies of RFLP associated with hGH gene cluster in unrelated subjects with CSS and unrelated normal children as controls

\begin{tabular}{lccc}
\hline & $\begin{array}{c}\text { RFLP alleles } \\
(\mathrm{kb})\end{array}$ & $\begin{array}{c}\text { CSS } \\
n=40\end{array}$ & $\begin{array}{c}\text { Controls } \\
n=50\end{array}$ \\
\hline HincII & $6.7 / 4.5$ & $63 / 37$ & $59 / 41$ \\
MspI(A) & $4.3 / 3.6$ & $45 / 55$ & $49 / 51$ \\
MspI(B) & $3.9 / 3.3$ & $40 / 60$ & $40 / 60$ \\
Bg/II(A) & $13.0 / 10.5$ & $40 / 60$ & $39 / 61$ \\
Bg/II(B) & $8.1 / 3.0$ & $58 / 42$ & $54 / 46$ \\
\hline
\end{tabular}

reported (12). Our data do not support this finding, inasmuch as we found an identical allelic frequency for the $13.0-\mathrm{kb}$ allele in children with CSS (7\%), children of normal height (8\%) for age and sex (13), and children with IGHD (7\%). There is no obvious explanation for the difference in allelic frequencies found in the normal British and French populations. In addition, our linkage data exclude a dominant effect of the IGF-I gene in CSS.

In another study, using ribonuclease protection assay, no common variations in the coding or noncoding regions of the
IGF-I gene were found in subjects with CSS (11). These data and our findings support the idea that the IGF-I gene is a highly conserved gene and does not play an important part in determining growth failure in individuals with CSS.

Using the hGH gene probe, the presence of $25-\mathrm{kb}$ HindIII and $3.8-\mathrm{kb}$ Bam HI fragments and the absence of an additional HindIII fragment of 18.3 or $17.4 \mathrm{~kb}$ indicates that all subjects with CSS carried all five genes of the hGH cluster. The allelic frequencies of the five common RFLP and the distribution of the different haplotypes did not differ in the CSS, normal, and IGHD groups of children. These data extend the spectrum of growth disorders in which the hGH gene cluster has been studied and enable us to conclude that structural abnormalities of the $\mathrm{hGH}$ gene cluster detectable by restriction endonuclease analysis are only very rarely causes for growth failure.

Acknowledgments. The authors thank Dr. David Curtis, research fellow in Molecular Psychiatry, and Robin Sherrington, Molecular Psychiatry, The Middlesex Hospital, for their helpful discussion and assistance in performing the linkage analysis.

Table 3. Distribution of haplotypes in the hGH gene cluster in subjects with CSS and in controls of normal stature*

\begin{tabular}{|c|c|c|c|c|c|c|c|c|c|}
\hline \multirow{2}{*}{$\begin{array}{c}\text { Hincll } \\
(6.7 / 4.5 \mathrm{~kb})\end{array}$} & \multirow{2}{*}{$\begin{array}{c}M s p I(\mathrm{~A}) \\
(4.3 / 3.6 \mathrm{~kb})\end{array}$} & \multirow{2}{*}{$\begin{array}{c}M s p \mathrm{I}(\mathrm{B}) \\
(3.9 / 3.3 \mathrm{~kb})\end{array}$} & \multirow{2}{*}{$\begin{array}{c}B g / \mathrm{II}(\mathrm{A}) \\
(13 / 10.5 \mathrm{~kb})\end{array}$} & \multicolumn{3}{|c|}{ Subjects with CSS } & \multicolumn{3}{|c|}{ Subjects of normal height } \\
\hline & & & & $n$ & $\%$ & $\hat{\mathrm{P}}$ & $n$ & $\%$ & $\hat{\mathrm{P}}$ \\
\hline+ & + & + & + & 3 & 5.5 & $0.05 \pm 0.031$ & 1 & 2.7 & $0.03 \pm 0.028$ \\
\hline+ & + & + & - & 17 & 31.5 & $0.32 \pm 0.062$ & 12 & 33.0 & $0.33 \pm 0.078$ \\
\hline+ & - & - & + & 2 & 3.7 & $0.04 \pm 0.025$ & 1 & 2.7 & $0.03 \pm 0.028$ \\
\hline - & + & + & + & 11 & 20.3 & $0.20 \pm 0.054$ & 7 & 19.4 & $0.19 \pm 0.065$ \\
\hline - & + & - & + & 3 & 5.5 & $0.05 \pm 0.031$ & 2 & 5.5 & $0.05 \pm 0.037$ \\
\hline - & + & + & - & 3 & 5.5 & $0.05 \pm 0.031$ & 3 & 8.3 & $0.08 \pm 0.045$ \\
\hline - & - & - & + & 15 & 27.8 & $0.28 \pm 0.06$ & 10 & 27.7 & $0.27 \pm 0.073$ \\
\hline
\end{tabular}

* For each RFLP, - indicates the presence of the larger allelic restriction fragment and + the presence of the shorter allelic restriction fragment. $\hat{\mathrm{P}}$ is the maximum likelihood estimate and its SEM for each haplotype. 


\section{REFERENCES}

1. Froesch ER, Schmid C, Schwander J, Zapf J 1985 Actions of insulin-like growth factors. Annu Rev Physiol 47:443-467

2. Hindmarsh P, Smith PJ, Brook CGD, Matthews DR 1987 The relationship between height velocity and growth hormone secretion in short prepubertal children. Clin Endocrinol (Oxf) 27:581-591

3. Hindmarsh PC, Pringle PJ, Di Silvio L, Brook CGD 1990 Effects of 3 years growth hormone therapy in short normal children. Acta Paediatr Scand [Suppl] 366:6-12

4. Genentech Collaborative Study Group 1990 Response to growth hormone in children with idiopathic short stature. Acta Paediatr Scand 366:24-26

5. Brook CGD, Hindmarsh PC, Smith PJ 1987 Is growth hormone deficiency a useful diagnosis? Acta Paediatr Scand [Suppl] 331:70-75

6. Milner RDG, Burns EC 1982 Investigation of suspected growth hormone deficiency. Arch Dis Child 57:944-947

7. Mathews LS, Norstedt G, Palmiter RD 1986 Regulation of insulin-like growth factor I gene expression by growth hormone. Proc Natl Acad Sci USA 83:9343-9347

8. Chen EY, Liao YC, Smith DH, Barrera-Saldana HA, Gelinas RE, Seeburg PH 1989 The human growth hormone locus: nucleotide sequence, biology, and evolution. Genomics 4:479-497

9. Rotwein P 1986 Two insulin-like growth factor I messenger RNAs are expressed in human liver. Proc Natl Acad Sci USA 83:77-81

10. Tricoli JV, Rall LB, Scott J, Bell GI, Shows TB 1984 Localization of insulinlike growth factor genes to human chromosomes 11 and 12. Nature 310:784786

11. Lajara R, Galgani JP, Dempsher DP, Bier DM, Rotwein P 1990 Low prevalence of insulin-like growth factor I gene mutations in human growth disorders. J Clin Endocrinol Metab 70:687-692

12. Schneid H, Le Bouc Y, Seurin D, Gourmelen M, Cabrol S, Raux-Demay MC, Girard F, Binoux M 1990 Insulin-like growth factor-I gene analysis in subjects with constitutionally variant stature. Pediatr Res 27:488-491

13. Tanner JM, Whitehouse RH, Takaishi M 1966 Standards from birth to maturity for height, weight, height velocity and weight velocity: British children. Part II. Arch Dis Child 41:613-635

14. Tanner JM, Whitehouse RH, Hughes PC, Vince FP 1971 Effect of human growth hormone treatment for $1-7$ years on growth of 100 children with growth hormone deficiency, low birthweight, inherited smallness. Turner's syndrome and other complaints. Arch Dis Child 46:745-782

15. Brook CGD 1982 Growth Assessment in Childhood and Adolescence. Blackwell, Oxford

16. Mullis P, Patel M, Brickell PM, Brook CGD 1990 Isolated growth hormone deficiency: analysis of the growth hormone $(\mathrm{GH})$ releasing hormone gene and the GH gene cluster. J Clin Endocrinol Metab 70:187-191

17. Chakravati A, Phillips JA, Mellits KH, Buetow KH, Seeburg PH 1984 Patterns of polymorphism and linkage disequilibrium suggest independent origins of the human growth hormone gene cluster. Proc Natl Acad Sci USA 81:60856089

18. Höppener JWM, de Patger-Holthuizen P, Geurts van Kessel AHM 1985 The human gene encoding insulin-like growth factor I is located in chromosome 12. Hum Genet 69:157-160

19. Blethan SL, Chasalow FI 1983 Use of a two-site immunoradiometric assay for growth hormone (GHO in identifying children with $\mathrm{GH}$ dependent growth failure. J Clin Endocrinol Metab 57:1031-1035

20. Martial JA, Hallewell RA, Baxter JD, Goodman HM 1979 Human growth hormone: complementary DNA cloning and expression in bacteria. Science 205:602-607

21. Le Bouc Y, Dreyer D, Jaeger F, Binoux M, Sondermeyer P 1986 Complete characterization of the human IGF-I nucleotide sequence isolated from a newly constructed adult liver cDNA library. FEBS Lett 196:108-112

22. Feinberg AP, Vogelstein B 1984 A technique for radiolabeling DNA restriction endonuclease fragments to high specific activity. Anal Biochem 137:266267

23. Sambrook J, Fritsch EF, Maniatis $\Upsilon 1989$ Molecular Cloning: A Laboratory Manual. Cold Spring Harbor Laboratory, Cold Spring Harbor, NY

24. Schneid H, Noguiez P, Girard F, Binoux M, Le Boux Y 1988 Eco RV RFLP at the insulin-like growth factor (IGF-I) locus on chromosome 12 . Nucleic Acids Res 16:9059

25. Ott J 1985 Linkage Package: Analysis of Human Genetic Linkage. John Hopkins University Press, Baltimore 